\title{
第66回日本内科学会䓦演会 (1969年)
}

\section{シンポジゥム 喘＼cjkstart息}

（7）予定発言 喘息の心肺機能，治療の立場加ら

\author{
名古屋大学医学部第二内科 \\ 讙師佐 竹辰 夫

\section{SYMPOSIUM ON ASTHMA. CARDIOPULMONARY FUNCTIONS \\ IN ASTHMATIC ATTACKS, FROM THE \\ STANDPOINT OF ALLOPATHIES}

Tatsuo Satake

The Second Department of Internal Medicine, School of Medicine, Nagoya University, Nagoya

治療法は原因によつて異なりアアトピー型には 減感作療法，感染型には去痰剂と抗生物質などの 投与が必要となる。ここでは，それらの無効例や 減感作中に起こる発作の緩解に対して必要な対症 療法につき, 病態生理の解明から得た知識と体験 をもとK，考慮すべき重要な二，三の点を総括的 に述べる.

\section{§1. 心肺機能からみた発作中の病態生理}

1 秒量 $1.52 \pm 0.62 l$ ( 1 秒率 $51 \pm 11 \%$ ) 程度の 中発作では，63土15\%の肺胞気道系が気道壁およ び/るいは肺胞壁の滑平筋収縮などにより換気 不良肺胞群となり，その換気血流比は0.25士0.07 へ低下して低酸素血症の主因を作る. 反面， $8 \pm$ $7 \%$ 肺胞群が代償性に過剩換気となり，その換 気血流比は 5.0 以上へ移行する。このため, 肺全 体に括ける換気血流比の異常分布は著るしく㹡が り，酸素と炭酸ガスの換気当量と循環当量が著增 し，肺之心の仕事量が急增するにもかかからず ガス交換効率が悪化する.そして，このような exertionとefficiencyの間の不均衝が喘鳴を伴う発 作性呼吸困難, 息切的 (sensation) の発症原因に なつていることが確かめられだ．この状態をル チン検査でみると，換気障害の指標である 1 秒量
の減少は，息切れ $(\gamma=-0.567)$ や音〜喘鳴 $(\gamma=-0.685)$ の程度と相関しない例があり， また，低酸素血症 $(r=0.802)$ の程度之も，そ れが換気障害の程度以外に換気不良肺胞群に括け る肺胞毛細血管の収縮態度 ${ }^{2)}$ や混合静脈血のガス 変化にも左右されるる゙ ため，密接には相関しない 例のあることが認められた。このため，治療法の 適応を決めるには，a）息切れそのもの，b）息 切れ，喘鳴と換気障害のみ，c）息切れと換気障 害に著るしい血液ガス変化を伴つたもの，の3者 に分け，体系化してチェックしていく必要がある 5. 以下，この考えに基ついて述べる.

\section{§2. 息切れ (sensation)の発症闇值亡治療}

息切れ発症の閾值をlength-tension method ${ }^{4}$ で 測定したところ，慢性肺気腫患者の $100 \mathrm{cmH}_{2} \mathrm{O} / \mathrm{L}$ 以上に反し，気管支喘息患者では $60 \mathrm{cmH}_{2} \mathrm{O} / \mathrm{L}$ 以 下と比較的敏感になつていることが分かつた。 こ の結果は，喘息では肺気腫に合併したものを除い て心肺機能障害の程度を上回る息切れのsensation があり，かつ，これを除くには炭酸がスの異常貯 留がない限り鎮静剤や精神安定版を与えて差し支 气ないことを示すものと考党られた。

§3。吸入療法，および，その効果からみた気管 


\section{支喘息と気管支炎の比較}

息切れ，喘鳴之換気障害のみで動脈血ガス変化 が著しくない例では病变が主に上気道にあり，一 般には気管支拡張剤の吸入が適応となる。この場 合，比較的大きな粒子が多く，かつ，2〜3 回の 吸入に止まるspraykよる投与でも，I P P B に よる投与に近い改善成績が得られた。また，同程 度の換気障害の喘息群之気管支炎群とで吸入効果 を比較したところ，同じ程度の可逆性をもつこと も分かつだ．この結果は，両者の鑑別が可逆性 試験のみでは不可能なこと，両者の気管支病変 が類似していること，などを示唆したものと云え る.

他方，とくに感染型では発作時に喀痰の粘性や 表面張力と総蛋白量，D NA，カルンウムなどが 平行して高まる症例があり，これらには，子ちろ ん, 喀痰溶解郕, 去痰郕などの吸入を加兄る必要 がある。

\section{§4. 間歇的陽圧呼吸 (IPPB) 療法}

血液ガス変化，とくに動脈血酸素分圧が $60 \mathrm{~mm} H \mathrm{Hg}$ 以下の例では病変が末梢の気道に拉よんで拈り， 通常，気管支拡張剂，喀疹溶解剂などを $40 \%$ 酸素 とともにIPPBで炭酸がスの蓄積を避けながら投 与する方法が藍められている，そこで，IPPB自 体の生理作用を検討したところ，自発的過剩換気 の場合よりも少ない換気仕事量の増加で換気不良 肺胞群に対する換気量を増加させうること，すな わち，薬剤之高酸素ガスの到達が充分に行なわれ ることが分かつた，一方，肺胞胸䑰内圧の上昇に よる肺循環障害については，肺気腫に合併した喘 息以外，さ程考虑する必要がないことも分かつ た6).

\section{\$5. 大発作時の心肺機能と治療}

大発作では動脈血の酸素分王が50 $\mathrm{mm} \mathrm{Hg}$ 前後ある いは以下になり，それ自体が脳や心葴の機能を直 接に障害するが7)，IPPBの施行は不可能な状態 にある，その他，とくに注目すべきは肺循環の変 化であり，発作そのるのでは肺動脈平均圧は 25 m血价前後に止まるが，最も危険なのは咳が連続し た場合であり，数回の重積で胸䐑内圧は著しく上 昇, 肺動脈平均圧す50mm Hg上人急上昇し，か つ，かなりの時間にわたり持続されることが分か つた.この状態は, 静脈還流 ( 心拍出量)を抑 制する ${ }^{8)}$ ともに右室心筋組織の平均酸素分王を 圧負荷により直接に10 m $\mathrm{mg}$ 以下八著减させて急性 右心不全を起こすこと，すなわち，発作死の主因 を作るものと判断され，さらに，右室肥大をも つ症例ではこの傾向が促進されることも分かつ た9).もちろん, a minophyllineなどの静注は早 急にこれら肺と心などの呼吸機能障害を直接好転 させるとともに，IPPBの吸入やほかの処置を容 易にし，それらの改善効果を促進することも分か つた.

協同研究者：飯田幸雄，巨井明生，飯田威夫， 龍華一男, 松阙輝樹, 山崎二郎, 石川能正, 石川 裕

\section{文献}

1）传竹厔夫：気管支喘息の病態生理，とくに呼吸 因難の成因に上めるガス交换障害上血夜ガス变化 について、フレルギー, $16: 683,1967$. -2) 佐竹辰 夫：呼吸機能障害と肺循環，第17回日本医学会総会

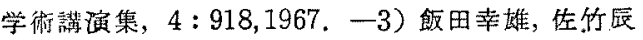
夫ほか：治療による慢性肺気腫患者のスパイロクラ ム，血液がス，心電図所見における可逆性の実態と 限界，および，それらの相亚関䋆にかんする研究， 日内会誌，58:491，1969. -4) Howell, J.B.L. and E.J.M. Campbell (eds.): Breathlessness. Blackwell Scientific Publications, Oxford, 1966. 一5)佐竹辰夫ほか：碩固な病歴を的つ閉塞性肺疾 患, とくに気管支揣息比関する気管支扗張剤isoprophenamineの使用経験 (吸入奻果および長期内服), 浐療， $21: 1171 ， 1968$. 一6) 白井明生：慢性肺気 尰患者之気管支喘息患者の間歇的陽王呼吸中なら びに自発的過剩換気中における肺内ガス交換に関 する研究，とくに换気分布と血流分布の变動につい て, 日㹸学誌, $32: 1499,1968 .-7$ ) Satake, T.: Cardiac and pulmonary responeses in men under hypoxic conditions, Int. J. Biometeor. $11: 129$, 1267. 一8）片阊：呼吸变動の肺循瞢および肺循 環調節に及ぼす影整に関する実驗的研究, 日循学 誌, $29: 661,1965$. 一9) 佐竹辰夫：慢性肺性心 の病態生理にかんする研究，特に右心不全の成因に 占める肺性肺高王, 低酸素, 高炭酸ガス及び右室肥 大の役割について, 日本胸部蹦木, $28: 91,1969$. 